\title{
Hemodynamics of Leptomeningeal Collaterals after Large Vessel Occlusion and Blood Pressure Management with Endovascular Treatment
}

\author{
Beom Joon Kim, ${ }^{\mathrm{a}}$ Nishita Singh, ${ }^{\mathrm{b}}$ Bijoy K. Menon ${ }^{\mathrm{b}}$ \\ aDepartment of Neurology and Cerebrovascular Center, Seoul National University Bundang Hospital, Seongnam, Korea \\ bDepartment of Clinical Neurosciences, Foothills Medical Center, University of Calgary, Calgary, AB, Canada
}

Endovascular therapy (EVT) is an effective treatment for ischemic stroke due to large vessel occlusion (LVO). Unlike intravenous thrombolysis, EVT enables visualization of the restoration of blood flow, also known as successful reperfusion in real time. However, until successful reperfusion is achieved, the survival of the ischemic brain is mainly dependent on blood flow from the leptomeningeal collaterals (LMC). It plays a critical role in maintaining tissue perfusion after LVO via pre-existing channels between the arborizing pial small arteries or arterioles overlying the cerebral hemispheres. In the ischemic territory where the physiologic cerebral autoregulation is impaired and the pial arteries are maximally dilated within their capacity, the direction and amount of LMC perfusion rely on the systemic perfusion, which can be estimated by measuring blood pressure (BP). After the EVT procedure, treatment focuses on mitigating the risk of hemorrhagic transformation, potentially via BP reduction. Thus, BP management may be a key component of acute care for patients with LVO stroke. However, the guidelines on BP management during and after EVT are limited, mostly due to the scarcity of high-level evidence on this issue. In this review, we aim to summarize the anatomical and physiological characteristics of LMC to maintain cerebral perfusion after acute LVO, along with a landscape summary of the literature on $\mathrm{BP}$ management in endovascular treatment. The objective of this review is to describe the mechanistic association between systemic BP and collateral perfusion after LVO and thus provide clinical and research perspectives on this topic.

Keywords Leptomeningeal collateral; Blood pressure; Large vessel occlusion; Cerebrovascular circulation; Endovascular recanalization; Ischemic stroke
Correspondence: Beom Joon Kim Department of Neurology and Cerebrovascular Center, Seoul National University Bundang Hospital, 82 Gumiro 173beon-gil, Bundang-gu, Seongnam 13620, Korea

Tel: +82-31-787-7468

Fax: +82-31-787-4059

E-mail:Kim.BJ.Stroke@gmail.com https://orcid.org/0000-0002-2719-3012

Received: July 10, 2021

Revised: September 3, 2021

Accepted: September 9, 2021

\section{Introduction}

The efficacy of intravenous thrombolysis (IVT) and endovascular therapy (EVT) for acute ischemic stroke patients after large vessel occlusion (LVO) has been established by large randomized clinical trials. ${ }^{1}$ However, approximately $50 \%$ of patients still experience functional dependency despite successful reca- nalization after timely treatment. ${ }^{1}$ Variability in collateral perfusion before recanalization may be a potential reason for this. ${ }^{2}$

The fate of brain cells in the ischemic region beyond the LVO depends on perfusion through the leptomeningeal collateral (LMC) overlying the cerebral hemisphere. Inadequate LMCs, either due to anatomical paucity or physiological dysfunction, lead to rapid infarct growth and may contribute to the pro- 
gression of ischemia after LVO. ${ }^{3}$ LMCs are an evolutionarily conserved anatomic structure but show substantial variability by species and individuals. ${ }^{4}$ Left ventricular contraction determines the degree of systemic blood circulation; similarly, the direction and flow of LMC perfusion depends on hydrostatic pressure gradients between the arteriolar and venular ends of cerebral blood vessels. ${ }^{5}$ After the loss of cerebral autoregulation (CA) in the region of severely depressed perfusion, ${ }^{6}$ cerebral blood flow (CBF) to the ischemic territory is predominantly a function of systemic perfusion pressure. Thus, systemic blood pressure (BP) may be regarded as an indirect measure of LMC perfusion. Modulation of LMC perfusion via systemic BP could therefore help maximize functional benefits during acute stroke care.

This article outlines how knowledge of the anatomy and physiology of LMCs may be applied clinically and provides an overview of current evidence on BP management during and after endovascular treatment, as well as its influence on treatment outcomes. In the absence of randomized controlled trial evidence, the purpose of this review is to help stroke physicians develop an anatomo-physiological model-based approach to BP management while caring for patients with LVO stroke.

\section{Anatomy and physiology of leptomeningeal collaterals}

\section{Anatomy}

In a normal physiological state, blood flows from the heart to the brain via the anterior circulation, which comprises the internal carotid artery, the middle cerebral artery (MCA), which supplies the majority of this circulation, and the anterior cerebral artery (ACA). Blood also flows via the posterior circulation, which is formed by the vertebral artery, basilar artery, and posterior cerebral artery (PCA). The average diameter of the MCA at its origin is approximately $4 \mathrm{~mm}$, roughly twice that of the ACA, which is approximately $2 \mathrm{~mm} .^{7,8}$ As the amount of blood flow roughly corresponds to the vascular diameter, the average CBF in the MCA $(146 \pm 31 \mathrm{~mL} / \mathrm{min})$ usually exceeds the flow in the ACA $(82 \pm 18 \mathrm{~mL} / \mathrm{min}){ }^{9}$

On the surface of the cerebral hemisphere, the pial arteries lie within the subarachnoid space and provide perforating arteries into the brain parenchyma. The proximal part of the perforating arteries usually consists of an endothelium surrounded by a thick basement membrane material with embedded smooth muscle cells. However, at the capillary level, the vascular wall consists of a single layer of flattened endothelial cells with a very thin basement membrane and intermittent pericytes without smooth muscle cells. ${ }^{10}$ The diameter of perforat- ing arterioles varies by its function and location, and can range from 10 to $240 \mu \mathrm{m}$, with the largest one penetrating to the bottom of the sulci. ${ }^{11}$

LMC channels consist of small precapillary arterial conduits of varying sizes lying between the pial arteries and arterioles in the cerebral cortex. There are two types of precapillary links: a larger one that connects the surface pial arteries in an end-toend manner, and a smaller one that bridges smaller perforating arterioles often near the point of cortical penetration. The diameter of these anastomoses shows a wide range (10 to 30 $\mu \mathrm{m})$ in their resting state. "1 These anastomotic channels work as the anatomical substrate of LMCs beyond an LVO.

\section{Physiology}

Perfusion through the arterial/arteriolar anastomoses described above is regulated by CA. CA is a normal physiological response that maintains constant blood flow in response to external and internal stimuli, such as changes in arterial BP between a mean arterial pressure (MAP) of 50 to $170 \mathrm{~mm} \mathrm{Hg} \cdot{ }^{12,13} \mathrm{CA}$ provides adequate regional $\mathrm{CBF}$ in settings of decreased systemic perfusion or increased local metabolic demand after neuronal/cellular hyperactivity. CA is regulated by a complex interplay of myogenic, neurogenic, metabolic, and endothelial mechanisms, ${ }^{14}$ all of which modulate the diameter of cerebral vessels. Vascular smooth muscle cells at the precapillary level regulate the vascular diameter through nitric oxide from endothelial cells, neurogenic substances, and cellular metabolic by-products. ${ }^{15-17}$ At the capillary level where smooth muscle cells are not found, the pericyte at the arteriolar side may contribute to vessel diameter modulation. ${ }^{18}$

As CA depends on the regulation of arteriolar diameters, the functional capacity of CA is determined by the structural and functional properties of the pial artery and arteriolar anastomoses. The normal physiological response of vasodilation to decreased perfusion pressure is altered in various pathological conditions such as aging, long-standing hypertension, and hyperglycemia. ${ }^{19-21}$ This resulting impairment in the CA response is not an all-or-none phenomenon but rather a graded and variable response (Figure 1). ${ }^{22,23}$

Leptomeningeal collateral perfusion and systemic blood pressure after large vessel occlusion

After LVO, a significant drop in local perfusion pressure occurs within the affected vascular territory, resulting in a mismatch between metabolic demand and oxygen/nutritional supply. In response to this, LMCs are recruited by vasodilation of the pial arteries and arteriolar anastomoses to their maximum available capacity. The average diameter of these anastomoses is less 


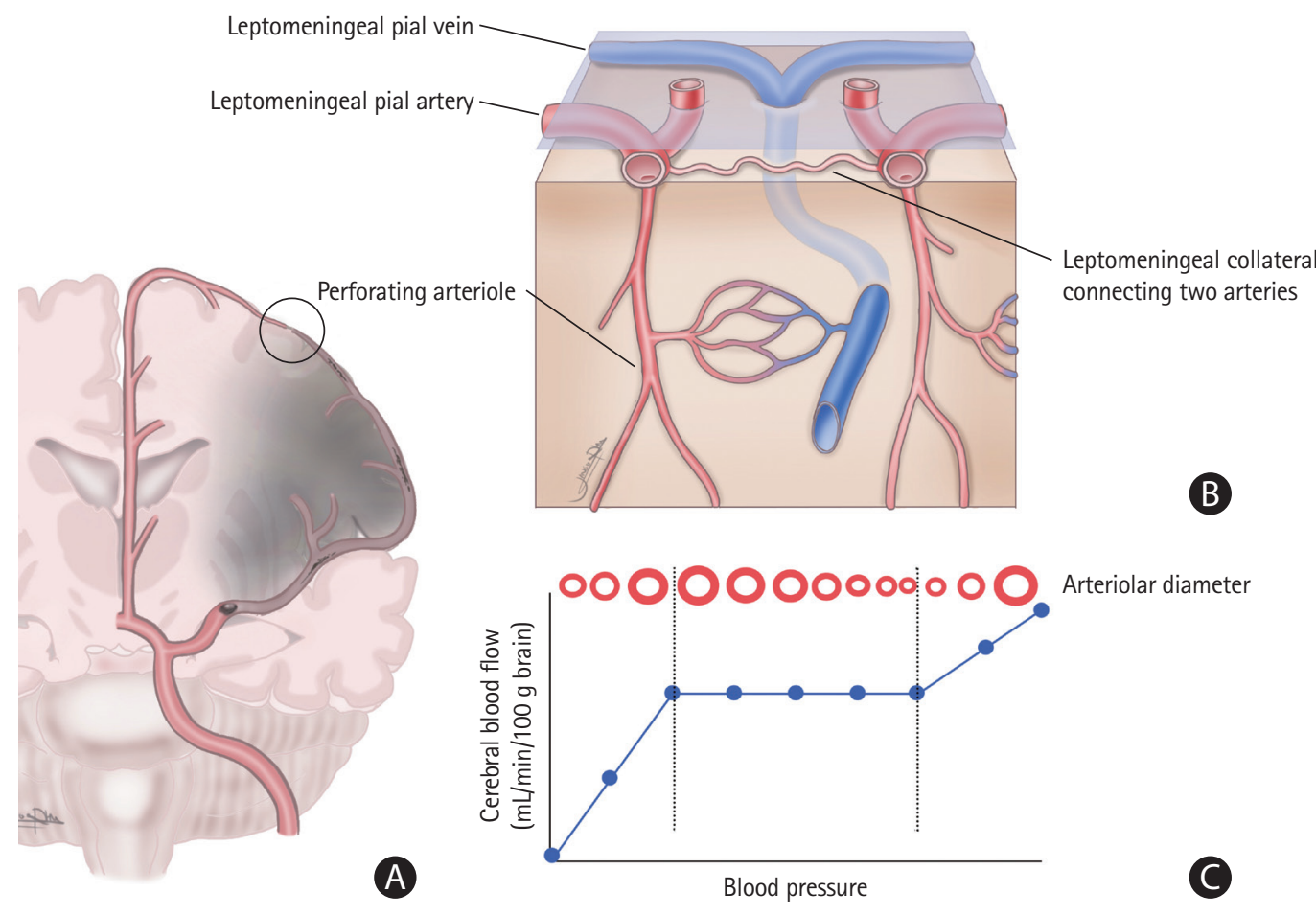

Figure 1. Overview of leptomeningeal collaterals and cerebral autoregulation. (A) When a perfusion pressure gradient develops after large vessel occlusion, leptomeningeal collaterals are instantaneously recruited to provide cerebral perfusion to the ischemic territory within the functional capacity of cerebral autoregulation. (B) Microscopically, leptomeningeal collateral channels utilize pre-existing arterial tubular structures between the pial arteries, arterioles, or proximal branches. (C) The recruitment of leptomeningeal channels depends primarily on the myogenic dilatation of the pial arteries responsive to decreased local perfusion pressure (i.e., cerebral autoregulation).

than 10 to $20 \mu \mathrm{m}$ in the resting state, but when fully recruited after LVO, their diameter increases almost 6-fold (60 to 120 $\mu \mathrm{m}){ }^{24}$ Experimental animal model data have shown that this recruitment occurs almost instantaneously after LVO and takes an average of 12 seconds to reach a maximum. ${ }^{25}$ As the direction of blood flow through the LMC channel is determined by the perfusion pressure gradient at both ends of the conduit, ${ }_{1}^{26}$ the collateral perfusion passively flows from the ACA or PCA to the ischemic territory in the case of MCA occlusion.

Before successful recanalization is achieved after LVO, the objective of medical management is to prevent irreversible infarction of the ischemic penumbra. Cerebral autoregulatory mechanisms are unable to provide adequate regional CBF due to the severely depressed level of perfusion pressure, ${ }^{27}$ with the cardiac output now becoming the sole driving force of regional CBF. Informed by this physiological model, stroke physicians do not intentionally lower BP in acute ischemic stroke patients unless it is extremely high. ${ }^{28,29}$ However, this simple physiological model does not fully consider the complex interplay between any remaining CA capacity, extent and amount of LMC perfusion, and systemic BP. ${ }^{30}$ In this sense, early infarct growth will be a function of time from onset, ischemic severity, that is, baseline LMC perfusion, and tissue vulnerability. ${ }^{31,32}$
After successful recanalization, the objective of BP management should be to mitigate the risk of hemorrhagic transformation. The prevailing belief is that lowering BP may prevent hemorrhagic transformation after EVT. However, this simple model does not consider the fact that angiographic recanalization does not always guarantee tissue reperfusion. Examples of such physiology include the "no-reflow" phenomenon and partial recanalization, ${ }^{33,34}$ situations in which patients may benefit from relatively higher local perfusion pressure. ${ }^{35}$

\section{Levels and variabilities of blood pressure in peri-endovascular treatment and stroke outcomes}

In the early EVT era, studies mainly focused on one parameter for BP management: BP at the time of hospital arrival (Table 1). ${ }^{36-42}$ Both extremely high and low values of $B P$ on arrival were associated with poor functional recovery or hemorrhagic transformation after $\mathrm{EVT}^{36-38}$ The largest dataset to date on this topic was from the Multicenter Randomized Clinical Trial of Endovascular Treatment of Acute Ischemic Stroke in the Netherlands (MR CLEAN) registry with 3,180 EVT cases, which showed a J-shaped association between BP on admission and 
Table 1. Admission BP and EVT outcomes

\begin{tabular}{|c|c|c|c|c|}
\hline Study & Year & Study subjects & Major BP indices & Major findings \\
\hline Nogueira et al. ${ }^{36}$ & 2009 & $\begin{array}{l}305 \text { LVO patients included in } \\
\text { the MERCl and multi-MERCl } \\
\text { trials }\end{array}$ & BP on admission & $\begin{array}{l}\text { Higher SBP on admission associated with } \\
\text { unfavorable outcomes but an independent } \\
\text { predictor of successful recanalization }\end{array}$ \\
\hline Maier et al..$^{38}$ & 2017 & $\begin{array}{l}\text { 1,042 LVO patients with EVT } \\
\text { from ETIS registry }\end{array}$ & BP on admission & $\begin{array}{l}\text { Admission SBP showed J- or U-shaped association } \\
\text { with mortality, with the inflection point at SBP } \\
157 \mathrm{~mm} \mathrm{Hg}\end{array}$ \\
\hline Mulder et al. ${ }^{37}$ & 2017 & $\begin{array}{l}500 \text { LVO patients included in } \\
\text { the MR CLEAN trial }\end{array}$ & $\begin{array}{l}\text { BP at baseline, before EVT (for EVT } \\
\text { group) or stroke unit admission (for } \\
\text { the no-EVT group) }\end{array}$ & $\begin{array}{l}\text { Baseline SBP showed U-shape association with } \\
\text { functional outcome } \\
\text { High SBP associated with mortality and } \\
\text { symptomatic hemorrhage } \\
\text { No interaction between SBP level and EVT }\end{array}$ \\
\hline Goyal et al. ${ }^{41}$ & 2017 & 116 LVO patients with EVT & SBP on admission & $\begin{array}{l}\text { Admission SBP correlated with final infarct volume } \\
\text { Higher admission SBP associated with mRS 0-2 }\end{array}$ \\
\hline Schonenberger et al..$^{40 *}$ & 2018 & $\begin{array}{l}150 \text { EVT cases randomized to } \\
\text { GA or CS from the SIESTA trial }\end{array}$ & $\begin{array}{l}\text { BP measurements were divided into } \\
4 \text { phases: pre-EVT, } \\
\text { pre-recanalization, post- } \\
\text { recanalization, and post-EVT }\end{array}$ & $\begin{array}{l}\text { No association between the difference in SBP, DBP, } \\
\text { and MAP from baseline to the different phases of } \\
\text { intervention with 24-hour NIHSS } \\
\text { No association of BP drop with a change in mRS }\end{array}$ \\
\hline Anadani et al. ${ }^{42}$ & 2020 & $\begin{array}{l}381 \text { EVT cases from the } \\
\text { ASTER trial }\end{array}$ & Baseline BP prior to randomization & $\begin{array}{l}\text { No association between admission BP with mRS or } \\
\text { successful revascularization }\end{array}$ \\
\hline van den Berg et al..$^{39}$ & 2020 & $\begin{array}{l}3180 \text { EVT patients from the } \\
\text { MR CLEAN registry }\end{array}$ & BP on admission & $\begin{array}{l}\text { J-shaped association with } \mathrm{mRS} \text { and mortality with } \\
\text { inflection points at } 150 \text { and } 81 \mathrm{~mm} \mathrm{Hg} \\
\text { Higher SBP associated with poor } \mathrm{mRS} \text { and } \\
\text { mortality }\end{array}$ \\
\hline
\end{tabular}

BP, blood pressure; EVT, endovascular treatment; LVO, large vessel occlusion; MERCl, Mechanical Embolus Removal in Cerebral Ischemia Trial; Multi-MERCI, Multi Mechanical Embolus Removal in Cerebral Ischemia Trial; SBP, systolic blood pressure; ETIS, endovascular treatment in ischemic stroke follow-up evaluation study; MR CLEAN, Multicenter Randomized Clinical Trial of Endovascular Treatment of Acute Ischemic Stroke in the Netherlands; mRS, modified Rankin Scale; GA, general anesthesia; CS, conscious sedation; SIESTA, Sedation vs. Intubation for Endovascular Stroke Treatment trial; DBP, diastolic blood pressure; MAP, mean arterial pressure; NIHSS, National Institutes of Health Stroke Scale; ASTER, Contact Aspiration vs. Stent Retriever For Successful Revascularization trial.

*This article covers all peri-EVT periods.

mortality or functional recovery and an inflection point at $150 / 81 \mathrm{~mm} \mathrm{Hg} \cdot{ }^{39}$ However, BP at presentation is not modifiable.

The effect of procedural BP during EVT is mostly analyzed in conjunction with the type of anesthesia; therefore, the BP profile in such reports cannot be entirely distinguished from its influence (Table 2). ${ }^{40,43-61}$ It is not uncommon during general anesthesia $(G A)$ to have hypotensive episodes due to anesthesia drugs, intravascular hypovolemia, high intrathoracic pressures, and impaired sympathetic tone. ${ }^{62} \mathrm{GA}$ is usually correlated with lower BP levels and unfavorable outcomes compared to local anesthesia or conscious sedation. ${ }^{43,44}$ The Sedation vs. Intubation for Endovascular Stroke Treatment (SIESTA) and General or Local Anesthesia in Intra-arterial Therapy (GOLIATH) trials were conducted to investigate the association between anesthesia and EVT outcomes. ${ }^{63,64}$ Post hoc analyses of these trials reported that stroke outcomes were not associated with the magnitude of BP reduction and type of anesthesia. ${ }^{40,45}$ However, subsequent analyses showed that the degree of systolic blood pressure (SBP) or MAP reduction correlated with the volume of in- farction and with clinical deficits. ${ }^{46-48}$ When individual patient data were combined, longer cumulative durations of MAP less than $70 \mathrm{~mm} \mathrm{Hg}$ or greater than $90 \mathrm{~mm} \mathrm{Hg}$ were related to poor functional outcomes. ${ }^{49}$ Likewise, data from the MR CLEAN registry showed that a combination of prolonged duration of $\mathrm{BP}$ reduction with lower BP level was associated with worse 3-month outcomes. ${ }^{50}$

BP measurements obtained after EVT received more attention only after the effectiveness of EVT was proven in clinical trials (Table 3). 40,65-95 Studies have shown that higher BP after EVT correlates with a higher risk of hemorrhagic transformation, poor functional recovery, and mortality. ${ }^{65-69,96}$ The Blood Pressure after Endovascular Therapy for Ischemic Stroke (BEST) study, a multicenter study of 485 EVT cases collected from 12 comprehensive stroke centers, documented that peak SBP $<158 \mathrm{~mm} \mathrm{Hg} 24$ hours post-EVT was associated with an increased probability of good functional outcomes. ${ }^{70}$

Due to the relatively regular interval of BP measurements during the post-EVT phase, the effect of BP variability post-EVT has also been investigated well, with multiple studies showing 
Table 2. BP during the EVT procedure and outcomes

\begin{tabular}{|c|c|c|c|c|}
\hline Study & Year & Study subjects & Major BP indices & Major findings \\
\hline Davis et al. ${ }^{43}$ & 2012 & $96 \mathrm{EVT}$ cases (48 GA and $48 \mathrm{LA})$ & $\begin{array}{l}\text { SBP, DBP, and MAP (minimum and } \\
\text { maximum values for each) in LA } \\
\text { and GA groups }\end{array}$ & $\begin{array}{l}\text { Higher rates of mRS 0-2 in LA groups; lower SBP } \\
\text { levels in GA group }\end{array}$ \\
\hline Hendén et al..$^{53}$ & 2015 & $108 \mathrm{EVT}$ cases & $\begin{array}{l}\text { Fall in MAP of }>40 \% \text { compared to } \\
\text { the baseline under GA }\end{array}$ & $\begin{array}{l}\text { Fall in MAP of }>40 \% \text { from baseline associated } \\
\text { with poor neurological recovery }\end{array}$ \\
\hline John et al..$^{54}$ & 2015 & 147 EVT during 2008-2012 & $\begin{array}{l}\text { Levels of BP during the EVT } \\
\text { procedure under GA }\end{array}$ & $\begin{array}{l}\text { Lower maximum intraprocedural SBP associated } \\
\text { with mRS 0-2 }\end{array}$ \\
\hline Jagani et al. ${ }^{44}$ & 2016 & 99 EVT with CS or GA & $\begin{array}{l}\text { Maximum or minimum values of } \\
\text { SBP, DBP, and MAP }\end{array}$ & $\begin{array}{l}\text { GA associated with lower BP levels and poor } \\
\text { outcome }\end{array}$ \\
\hline Whalin et al. ${ }^{55}$ & 2017 & $\begin{array}{l}255 \text { Anterior circulation } \\
\text { occlusions with } \mathrm{mTICl} \geq 2 \mathrm{~b} \text { with } \\
\text { monitored anesthesia care }\end{array}$ & $\begin{array}{l}\text { MAP level during the procedure with } \\
\text { monitored anesthesia care }\end{array}$ & $\begin{array}{l}\text { 10\% MAP drop associated with poor functional } \\
\text { outcome }\end{array}$ \\
\hline Athiraman et al..$^{56}$ & 2018 & 88 EVTs under GA & $\begin{array}{l}\text { Episodes or durations of SBP lower } \\
\text { than specific thresholds }\end{array}$ & Lower SBP levels associated with poor outcome \\
\hline Pikija et al. ${ }^{46}$ & 2018 & $164 \mathrm{EVT}$ cases under GA & $\begin{array}{l}\text { In-procedure SBP and MAP } \\
\text { excursions to }>120 \% / 80 \% \text { of the } \\
\text { reference value and the reference } \\
\text { BP/weighted in-procedure mean BP }\end{array}$ & $\begin{array}{l}\text { High in-procedure SBP/MAP excursion to }>120 \% \\
\text { associated with lower infarct volume and mRS 0-2 } \\
\text { Higher in-procedure mean SBP/MAP associated } \\
\text { with lower rates of hemorrhage }\end{array}$ \\
\hline Rasmussen et al. ${ }^{45}$ & 2018 & $\begin{array}{l}128 \text { EVT patients randomized to } \\
\text { GA or CS from the GOLIATH } \\
\text { trial }\end{array}$ & $\begin{array}{l}\text { Levels and durations of SBP or MAP } \\
\text { lower than specific thresholds }\end{array}$ & $\begin{array}{l}\text { Higher MAP or SBP levels in CS group } \\
\text { No significant difference in the association } \\
\text { between BP parameters and mRS }\end{array}$ \\
\hline Schonenberger et al. ${ }^{40 *}$ & 2018 & $\begin{array}{l}150 \text { EVT cases randomized to GA } \\
\text { or CS from the SIESTA trial }\end{array}$ & $\begin{array}{l}\text { BP measurements were divided into } \\
4 \text { phases: pre-EVT, pre-recanalization, } \\
\text { post-recanalization, and post-EVT }\end{array}$ & $\begin{array}{l}\text { No association between the difference in SBP, DBP, } \\
\text { and MAP from baseline to the different phases } \\
\text { of intervention with } 24 \text { hours NIHSS } \\
\text { No association of BP drop (magnitude of changes) } \\
\text { with a change in mRS }\end{array}$ \\
\hline Treurniet et al. ${ }^{57}$ & 2018 & $\begin{array}{l}60 \text { EVT under GA in the MR } \\
\text { CLEAN trial }\end{array}$ & $\begin{array}{l}\text { Levels and changes of SBP, DBP, and } \\
\text { MAP during the procedure }\end{array}$ & $\begin{array}{l}\text { Greater MAP reduction associated with worse } \\
\text { functional outcome }\end{array}$ \\
\hline Petersen et al. ${ }^{47}$ & 2019 & $\begin{array}{l}390 \text { EVTs from two } \\
\text { comprehensive stroke centers }\end{array}$ & $\begin{array}{l}\text { Intraprocedural MAP, delta MAP } \\
\text { (baseline MAP-lowest MAP during } \\
\text { EVT procedures before } \\
\text { recanalization) }\end{array}$ & $\begin{array}{l}\text { MAP reduction noted in } 87 \% \text { of cases during EVT } \\
\text { Delta-MAP associated with infarct growth and } \\
\text { infarct volume; Delta-MAP correlated with } \\
\text { higher mRS at discharge }\end{array}$ \\
\hline Pikija et al..$^{58}$ & 2019 & $39 \mathrm{BAO}$ with EVT & $\begin{array}{l}\text { BP levels and variability indices; } \\
\text { difference of peak and trough } \\
\text { values, SD, CV, ARV; reference SBP } \\
\text { calculated as a median of the first } \\
\text { five procedural measurements }\end{array}$ & $\begin{array}{l}\text { Shorter procedural duration of SBP }<140 \\
\text { associated with successful recanalization } \\
\text { Higher SBP and longer duration of SBP over } \\
180 \mathrm{~mm} \mathrm{Hg} \text { associated with hemorrhage }\end{array}$ \\
\hline Fandler-Hofler et al. ${ }^{59}$ & 2020 & $\begin{array}{l}115 \text { Anterior circulation } \\
\text { occlusion patients with EVT } \\
\text { under GA }\end{array}$ & $\begin{array}{l}\text { Peri-interventional BP levels and } \\
\text { reduction }\end{array}$ & Single BP drop associated with poor outcome \\
\hline Maïer et al. ${ }^{51}$ & 2020 & $\begin{array}{l}381 \text { Patients from the ASTER } \\
\text { trial }\end{array}$ & $\begin{array}{l}\text { Dynamic BP parameter, CV; steady } \\
\text { BP parameter, hypotension time of } \\
\mathrm{SBP}<140 \text { or } \mathrm{MAP}<90\end{array}$ & $\begin{array}{l}\text { BP variability parameter associated with poor } \\
\text { outcomes regardless of collateral status } \\
\text { Hypotension time associated with poor outcomes } \\
\text { only in patients with poor collaterals }\end{array}$ \\
\hline Petersen et al. ${ }^{52}$ & 2020 & $\begin{array}{l}90 \text { EVTs for anterior circulation } \\
\text { occlusions }\end{array}$ & $\begin{array}{l}\text { Optimal ranges of MAP based on an } \\
\text { autoregulatory index calculated by } \\
\text { a real-time NIRS in response to } \\
\text { changes in MAP }\end{array}$ & $\begin{array}{l}\text { Percent time of MAP greater than the upper limit } \\
\text { of the optimal range associated with worse } 90- \\
\text { day outcomes and trends in hemorrhage }\end{array}$ \\
\hline Rasmussen et al. ${ }^{49}$ & 2020 & $\begin{array}{l}368 \text { EVT patient's data from } \\
\text { SIESTA, ANSTROKE, GOLIATH } \\
\text { trials (CS vs. GA) }\end{array}$ & $\begin{array}{l}\text { Levels and durations of MAP greater } \\
\text { or less than thresholds }\end{array}$ & $\begin{array}{l}\text { Cumulative hypo- (MABP }<70 \mathrm{~mm} \mathrm{Hg} \text { for }>10 \\
\text { minutes) and hypertension (MABP }>90 \mathrm{~mm} \mathrm{Hg} \text { for } \\
>45 \text { minutes) associated with poor functional } \\
\text { outcomes }\end{array}$ \\
\hline Valent et al. ${ }^{48}$ & 2020 & $371 \mathrm{EVT}$ cases under GA or CS & $\begin{array}{l}\text { Baseline BP; BP measured in the } \\
\text { interventional suite immediately } \\
\text { before the induction } \\
\text { Duration of arterial hypotension } \\
\text { (below the baseline BP) }\end{array}$ & $\begin{array}{l}\text { The time below } 90 \% \text { of the reference value } \\
\text { associated with } \mathrm{mRS} \geq 3\end{array}$ \\
\hline
\end{tabular}


Table 2. Continued

\begin{tabular}{|c|c|c|c|c|}
\hline Study & Year & Study subjects & Major BP indices & Major findings \\
\hline Samuels et al. ${ }^{50}$ & 2021 & $\begin{array}{l}440 \text { EVT patients from the MR } \\
\text { CLEAN registry, under CS or LA }\end{array}$ & Changes and duration of MAP levels & Lower MAP levels in CS; worse outcome in CS \\
\hline Xu et al. ${ }^{60}$ & 2021 & $\begin{array}{l}131 \text { EVT patients after LVO } \\
\text { under GA }\end{array}$ & $\begin{array}{l}\text { Delta MAP; MAP every } 5 \text { minutes- } \\
\text { baseline MAP } \\
\text { Cumulated time and the longest } \\
\text { continuous episode of delta MAP } \\
<10,15,20,25 \text {, and } 30 \mathrm{~mm} \mathrm{Hg}\end{array}$ & $\begin{array}{l}\text { Longer duration delta MAP associated with poor } \\
\text { outcome, but only documented in mild reduction } \\
\text { group }\end{array}$ \\
\hline Chen et al. ${ }^{61}$ & 2021 & $\begin{array}{l}139 \text { EVT cases with successful } \\
\text { recanalization }\end{array}$ & $\begin{array}{l}\text { Procedural BPs categorized into } \\
\text { baseline, pre-recanalization, post- } \\
\text { recanalization, and post-intervention }\end{array}$ & $\begin{array}{l}\text { High pre-recanalization BPs associated with poor } \\
\text { outcomes; protocol-based BP lowering during } \\
\text { EVT not associated with outcomes }\end{array}$ \\
\hline
\end{tabular}

BP, blood pressure; EVT, endovascular treatment; GA, general anesthesia; LA, local anesthesia; SBP, systolic blood pressure; DBP, diastolic blood pressure; MAP, mean arterial pressure; mRS, modified Rankin Scale; CS, conscious sedation; $\mathrm{mTICI}$, modified treatment in cerebral ischemia; GOLIATH, General or Local Anesthesia in Intra-arterial Therapy trial; SIESTA, Sedation vs. Intubation for Endovascular Stroke Treatment trial; NIHSS, National Institutes of Health Stroke Scale; MR CLEAN, Multicenter Randomized Clinical Trial of Endovascular Treatment of Acute Ischemic Stroke in the Netherlands; BAO, basilar artery occlusion; SD, standard deviation; CV, coefficient of variation; ARV, average real variation; ASTER, Contact Aspiration vs. Stent Retriever For Successful Revascularization trial; NIRS, near-infrared spectroscopy; ANSTROKE, Anesthesia During Stroke trial; MABP, mean arterial blood pressure; LVO, large vessel occlusion.

*This article covers all peri-EVT periods.

Table 3. Post-procedural BP and the recanalization treatment outcomes

\begin{tabular}{|c|c|c|c|c|}
\hline Study & Year & Study subjects & Major BP indices & Major findings \\
\hline Martins et al. ${ }^{79}$ & 2016 & 674 IVT or EVT cases & $\begin{array}{l}\text { BP every } 2 \text { hours for } 24 \text { hours after } \\
\text { admission }\end{array}$ & $\begin{array}{l}\text { SBP showed J-shape in non-recanalized group but } \\
\text { linear association in recanalized group }\end{array}$ \\
\hline Mistry et al..$^{80}$ & 2017 & $228 \mathrm{EVT}$ from three hospitals & $\begin{array}{l}\mathrm{BP} \text { ( } \max , \text { min, and average) in the } \\
\text { first } 24 \text { hours after EVT }\end{array}$ & $\begin{array}{l}\text { High peak SBP correlated with worse functional } \\
\text { outcome and hemorrhagic complications }\end{array}$ \\
\hline Goyal et al..$^{65}$ & 2017 & $\begin{array}{l}217 \text { LVO with EVT with hourly } \\
\text { BP }\end{array}$ & $\begin{array}{l}\text { BP goals post EVT; permissive } \\
\text { hypertension }(<220 \text { or } 185) \text {, } \\
\text { moderate BP control }(<160) \text {, } \\
\text { intensive BP control }(<140)\end{array}$ & $\begin{array}{l}\text { Higher SBPmax associated with mortality } \\
\text { Intensive } \mathrm{BP} \text { target }(<140 / 90 \mathrm{~mm} \mathrm{Hg}) \text { associated with } \\
\text { higher rates of } \mathrm{mRS} 0-2\end{array}$ \\
\hline Bennett et al. ${ }^{71}$ & 2018 & 182 LVO patients with EVT & $\begin{array}{l}\text { Post-procedural BP variability } \\
\text { indices; SD, CV, and SV }\end{array}$ & High BPV associated with high $\mathrm{mRS}$ \\
\hline Chang et al. ${ }^{81}$ & 2018 & 303 LVO patients with EVT & $\begin{array}{l}\text { Post-procedural BP variability } \\
\text { indices; SD, CV, and VIM }\end{array}$ & $\begin{array}{l}\text { High BPV associated with poor functional recovery } \\
\text { and low successful recanalization }\end{array}$ \\
\hline Maier et al. ${ }^{67}$ & 2018 & $\begin{array}{l}168 \text { Anterior circulation } \\
\text { occlusions with successful } \\
\text { recanalization after EVT }\end{array}$ & $\begin{array}{l}\text { Mean, max, and peak SBP for the } \\
\text { first } 24 \text { hours after successful EVT }\end{array}$ & $\begin{array}{l}\text { High mean SBP and maximum SBP associated with } \\
\text { unfavorable outcome }\end{array}$ \\
\hline Martins et al. ${ }^{82}$ & 2018 & $674 \mathrm{IVT}$ or EVT & $\begin{array}{l}\text { Standard deviations of SBP and DBP } \\
\text { during the first } 24 \text { hours after stroke }\end{array}$ & $\begin{array}{l}\text { A differential effect from SD of SBP on mRS by } \\
\text { recanalization status; significant only in non- } \\
\text { recanalized patients }\end{array}$ \\
\hline Schonenberger et al. ${ }^{40 *}$ & 2018 & $\begin{array}{l}150 \text { EVT cases randomized to } \\
\text { GA or CS from the SIESTA } \\
\text { trial }\end{array}$ & $\begin{array}{l}\text { BP measurements were divided into } \\
4 \text { phases: pre-EVT, pre-recanalization, } \\
\text { post-recanalization, and post-EVT }\end{array}$ & $\begin{array}{l}\text { No association between the difference in SBP, DBP, } \\
\text { and MAP from baseline to the different phases of } \\
\text { intervention and NIHSS change after } 24 \text { hours } \\
\text { No association of BP drops with a change in mRS }\end{array}$ \\
\hline Cernik et al. ${ }^{66}$ & 2019 & 690 EVT patients & Levels of SBP and DBP & $\begin{array}{l}\text { Low } \mathrm{BP} \text { levels associated with better functional } \\
\text { recovery or recanalization }\end{array}$ \\
\hline Chang et al..$^{83}$ & 2019 & $90 \mathrm{EVT}$ with $\mathrm{mTICl} \geq 2 \mathrm{~b}$ & $\mathrm{BP}$ variability indices & $\begin{array}{l}\text { BP variability associated with poor mRS only in } \\
\text { patients with poor collaterals at baseline }\end{array}$ \\
\hline Cho et al. ${ }^{84}$ & 2019 & 378 EVTs & $\begin{array}{l}\text { Levels and variability indices during } \\
\text { the first } 24 \text { hours after admission }\end{array}$ & $\begin{array}{l}\text { Higher mean SBP and SV of SBP associated with poor } \\
\text { mRS; the effect of SV modified by recanalization status }\end{array}$ \\
\hline Choi et al. ${ }^{85}$ & 2019 & $\begin{array}{l}\text { 1,540 AIS patients after IVT } \\
\text { or EVT }\end{array}$ & $\mathrm{BP} \leq 130 / 80 \mathrm{~mm} \mathrm{Hg}$ & Lower BP levels associated with mRS 0-2 \\
\hline Kim et al. ${ }^{73}$ & 2019 & 211 EVT with $\mathrm{mTICl} \geq 2 \mathrm{~b}$ & $\begin{array}{l}\text { Levels, excursions, variability indices, } \\
\text { and time rate of BP variation }\end{array}$ & $\begin{array}{l}\text { BP variability indices associated with higher rates of } \\
\text { SICH }\end{array}$ \\
\hline Mistry et al. ${ }^{70}$ & 2019 & $\begin{array}{l}485 \text { Consecutive EVT patients } \\
\text { from } 12 \text { centers }\end{array}$ & $\begin{array}{l}\text { All SBP values within } 24 \text { hours post } \\
\text { EVT }\end{array}$ & $\begin{array}{l}\text { Peak SBP }<158 \mathrm{~mm} \mathrm{Hg} \text { associated with good } \\
\text { functional outcome } \\
\text { Overall, SBP showed a U-shape association with outcome } \\
\text { Higher BP levels after EVT associated with poor outcome }\end{array}$ \\
\hline
\end{tabular}


Table 3. Continued

\begin{tabular}{|c|c|c|c|c|}
\hline Study & Year & Study subjects & Major BP indices & Major findings \\
\hline Zhang et al. ${ }^{86}$ & 2019 & 72 LVOs with EVT & $\begin{array}{l}\text { Post-procedural BP variability } \\
\text { indices; SD, CV, and SV }\end{array}$ & Higher SV of SBP correlated with mRS at 3 months \\
\hline Anadani et al. ${ }^{87}$ & 2020 & $\begin{array}{l}1,361 \mathrm{EVT} \text { cases from an } \\
\text { international multicenter } \\
\text { study }\end{array}$ & $\begin{array}{l}\text { SBP reduction in the first } 24 \text { hours } \\
\text { after EVT }\end{array}$ & $\begin{array}{l}\text { SBP reduction associated with a good outcome only in } \\
\text { patients with complete reperfusion }(\mathrm{mTICl}, 3)\end{array}$ \\
\hline Anadani et al. ${ }^{88}$ & 2020 & $\begin{array}{l}433 \text { EVT cases from the BEST } \\
\text { study }\end{array}$ & $\begin{array}{l}\text { SBP reduction, the absolute } \\
\text { difference between admission SBP } \\
\text { and mean SBP in the first } 24 \text { hours }\end{array}$ & $\begin{array}{l}\text { No association between SBP with poor outcome or } \\
\text { death }\end{array}$ \\
\hline Anadani et al. ${ }^{76}$ & 2020 & $\begin{array}{l}\text { 1,019 Anterior circulation } \\
\text { occlusion patients with EVT } \\
\text { from eight comprehensive } \\
\text { stroke centers }\end{array}$ & $\begin{array}{l}\text { Post-EVT BP target, }<140,<160, \\
\text { and }<180\end{array}$ & $\begin{array}{l}\text { Lower SBP goal }(<140 \text { or }<160 \text {, compared to }<180) \\
\text { associated with good outcome } \\
\text { However, mean achieved SBP levels tended to overlap }\end{array}$ \\
\hline Cheng et al. ${ }^{68}$ & 2020 & $\begin{array}{l}124 \text { Anterior circulation } \\
\text { occlusion patients with EVT }\end{array}$ & $\begin{array}{l}\text { Two BP measurements immediately } \\
\text { after successful recanalization }\end{array}$ & $\begin{array}{l}\text { Higher BP associated with } \mathrm{PH} 2 \text { hemorrhagic } \\
\text { transformation }\end{array}$ \\
\hline Chu et al. ${ }^{89}$ & 2019 & 166 EVT patients & $\begin{array}{l}\text { Hourly BP after EVT, by } 1-6,7-12 \text {, } \\
13-18 \text {, and } 19-24 \text { hours }\end{array}$ & $\begin{array}{l}\text { Lower mean, max, SD of SBP, and DBP associated with } \\
\text { functional independence, in }<6 \text { hours }\end{array}$ \\
\hline Dias et al. ${ }^{90}$ & 2020 & $458 \mathrm{EVT}$ cases & $\begin{array}{l}\text { Median SBP within the first hour } \\
\text { after EVT }\end{array}$ & $\begin{array}{l}\text { Lower median SBP associated with NIHSS reduction } \\
\text { by } 8 \text { or } \leq 2 \text { at } 24 \text { hours }\end{array}$ \\
\hline Ding et al. ${ }^{91}$ & 2020 & 262 EVT cases & $\begin{array}{l}\text { Maximum SBP and DBP for } 24 \text { hours } \\
\text { after the EVT }\end{array}$ & $\begin{array}{l}\text { Max SBP associated with poor mRS and parenchymal } \\
\text { hemorrhage (hyper attenuated lesion on immediate } \\
\text { CT, cannot distinguish from contrast staining) }\end{array}$ \\
\hline Matusevicius et al. ${ }^{69}$ & 2020 & $\begin{array}{l}\text { 3,631 EVT cases from the } \\
\text { SITS-ISTR }\end{array}$ & Mean 24-hour SBP after EVT & $\begin{array}{l}\text { Higher SBP associated with poor functional recovery } \\
\text { in successful recanalization patients and with SICH } \\
\text { in all recanalization }\end{array}$ \\
\hline McCarthy et al. ${ }^{92}$ & 2020 & $212 \mathrm{EVT}$ patients & Daily peak SBP and DBP & $\begin{array}{l}\text { Higher peak 24-hour SBP associated with SICH and } \\
\text { poor outcome } \\
\text { Higher peak SBP at day } 2 \text { and day } 3 \text { associated with } \\
\text { poor outcome }\end{array}$ \\
\hline Mistry et al. ${ }^{72}$ & 2020 & $\begin{array}{l}443 \text { EVT cases from the BEST } \\
\text { study }{ }^{70}\end{array}$ & $\begin{array}{l}\text { Systolic BPV (SD, CV, ARV, SV, and } \\
\text { rSD) during } 24 \text { hours after EVT }\end{array}$ & $\begin{array}{l}\text { Higher BP variability associated with poor outcome } \\
\text { and mortality }\end{array}$ \\
\hline Anadani et al. ${ }^{74}$ & 2021 & $\begin{array}{l}\text { 5,835 EVT patients from the } \\
\text { SITS-ISTR registry }\end{array}$ & $\begin{array}{r}\text { Delta SBP (SBP-baseline SBP) } \\
0-2 / 2-4 / 4-12 / 12-24 \text { hours }\end{array}$ & $\begin{array}{l}\text { SBP elevation after EVT associated with poor } \\
\text { functional outcome }\end{array}$ \\
\hline Gigliotti et al..$^{93}$ & 2021 & 117 EVT cases & SBP for 24 hours after EVT & $\begin{array}{l}\text { SBP } \geq 180 \text { associated with poor function at discharge } \\
\text { but not at } 3 \text { months } \\
\text { SBP } \geq 160 \text { associated with malignant cerebral edema } \\
\text { with lower symptomatic hemorrhage }\end{array}$ \\
\hline Han et al. ${ }^{94}$ & 2021 & $187 \mathrm{BAO}$ with $\mathrm{EVT}$ & Levels of SBP, MAP, and DBP & $\begin{array}{l}\text { Maximum SBP and maximum MAP associated with } \\
\text { mortality }\end{array}$ \\
\hline Huang et al. ${ }^{95}$ & 2021 & $\begin{array}{l}502 \text { Anterior circulation LVO } \\
\text { patients with EVT }\end{array}$ & $\begin{array}{l}\text { Levels and variability indices of SBP } \\
\text { and DBP }\end{array}$ & $\begin{array}{l}\text { High BP variability associated with poor functional } \\
\text { recovery and hemorrhagic complications, } \\
\text { differentiated by recanalization status, not by } \\
\text { baseline collaterals }\end{array}$ \\
\hline Liu et al. ${ }^{77}$ & 2021 & $\begin{array}{l}596 \text { LVO patients with EVT } \\
\text { (GA in } 37 \%)\end{array}$ & BP for 24 hours after EVT & $\begin{array}{l}\text { Higher mean SBP levels, mean SBP }>140 \text {, and SD of } \\
\text { SBP associated with the unfavorable outcome only } \\
\text { in poor collaterals subgroup }\end{array}$ \\
\hline Mazighi et al. ${ }^{75}$ & 2021 & $\begin{array}{l}324 \text { LVO patients with EVT } \\
\text { (BP-TARGET trial) }\end{array}$ & $\begin{array}{l}\text { Randomized to intensive SBP target } \\
(100-129) \text { vs. standard SBP target } \\
(130-185) \text { for } 24 \text { hours }\end{array}$ & $\begin{array}{l}\text { No difference in the primary outcome (any } \\
\text { hemorrhage or hypotensive event) }\end{array}$ \\
\hline Castro et al. ${ }^{78}$ & 2021 & $\begin{array}{l}146 \text { Anterior circulation LVO } \\
\text { with successful recanalization }\end{array}$ & $\begin{array}{l}\text { Spectral analysis of 5-minute } \\
\text { recordings of beat-to-beat BP }\end{array}$ & $\begin{array}{l}\text { High frequency BP variability associated with cerebral } \\
\text { edema and unfavorable functional outcomes }\end{array}$ \\
\hline
\end{tabular}

BP, blood pressure; IVT, intravenous thrombolysis; EVT, endovascular treatment; SBP, systolic blood pressure; LVO, large vessel occlusion; mRS, modified Rankin Scale; SD, standard deviation; CV, coefficient of variation; SV, successive variation; BPV, BP variability; VIM, variation independent of the mean; GA, general anesthesia; CS, conscious sedation; SIESTA, Sedation vs. Intubation for Endovascular Stroke Treatment trial; DBP, diastolic blood pressure; MAP, mean arterial pressure; NIHSS, National Institutes of Health Stroke Scale; mTICl, modified treatment in cerebral ischemia; AIS, acute ischemic stroke; SICH, symptomatic intracranial hemorrhage; BEST, Blood Pressure after Endovascular Therapy for Ischemic Stroke study; CT, computed tomography; PH2, parenchymal hemorrhage type 2; SITS-ISTR, Safe Implementation of Thrombolysis in Stroke International Stroke Thrombolysis Registry; ARV, average real variation; rSD, residual standard deviation; BAO, basilar artery occlusion; BP-TARGET, Blood Pressure target in Acute Stroke to Reduce Hemorrhage after Endovascular Therapy trial.

*This article covers all peri-EVT periods. 
that higher BP variability is associated with larger infarct volume and poor functional recovery. ${ }^{71,97}$ In a secondary analysis of the BEST study, it was shown that the correlation between BP levels and poor functional outcomes became more robust in the group with high BP variability, which suggests an additive effect of BP variability over absolute BP levels. ${ }^{72}$ One shortcoming of such analyses is the neglect of the time gap between BP measurements when measuring BP variability. To address this issue, the concept of the rate of BP change, that is, $\mathrm{mm} \mathrm{Hg} / \mathrm{min}$, was proposed. This rate of change in BP was associated with an increased risk of symptomatic hemorrhage after EVT in one study. ${ }^{73}$ Spontaneous reduction of BP after recanalization is well known. ${ }^{98}$ In the post-EVT phase, some studies have noted poor outcomes with less BP reduction in those who had relatively higher BP compared to the baseline. ${ }^{70,74}$ Current analyses of BP variability, however, continue to be limited. Future analyses may need to incorporate longer-term trajectories and the rapidity of changes in BP readings during the hyperacute period.

\section{Summary of current evidence for clinical practice}

\section{Current clinical guidelines and summary of the literature on BP management during the peri- endovascular treatment period}

The BP management recommendations from current guidelines may be summarized as follows: $:^{28,29}$

(1) Routine use of BP-lowering medication before recanalization treatment (thrombolysis and/or EVT) is not well established and is not recommended unless $>220 / 110 \mathrm{~mm} \mathrm{Hg}$.

(2) For IVT alone, it is recommended to maintain a BP $<185 / 110 \mathrm{~mm} \mathrm{Hg}$ before, during, and 24 hours after treatment.

(3) For EVT, intensive BP lowering in the peri-EVT period lacks clear benefits. It is suggested that BP be maintained at $<185 / 105 \mathrm{~mm} \mathrm{Hg}$ during and after the procedure. This recommendation was based on recent clinical trial protocols.

The landscape review from the previous section can be summarized as follows:

(1) Admission BP has a J- or U-shaped association with clinical outcomes after EVT.

(2) Prolonged duration of low BP during EVT procedures is associated with unfavorable outcomes.

(3) BP variability after EVT correlates with a higher risk of poor functional recovery and/or increased rates of hemorrhagic complications.

(4) Relatively lower BP reductions after EVT are associated with poor functional recovery.

\section{A tentative suggestion for the BP management of patients with EVT}

\section{Pre-EVT period}

The objective of BP management during this period should be to maximize the viability of the ischemic penumbra. The recent literature is inconclusive, with both higher or lower levels of admission BPs reported to be correlated with poor outcomes. Current guidelines recommend that EVT candidates maintain an SBP $<185 \mathrm{~mm} \mathrm{Hg}$. This BP threshold is a legacy from the eligibility criteria for the intravenous thrombolysis trial. ${ }^{99} \mathrm{Al}-$ though this threshold BP level was not validated in any of the EVT trials, there is currently no evidence to suggest any other threshold level in these patients. Likewise, there is still minimal evidence to support increased cerebral perfusion after an LVO stroke after iatrogenically induced hypertension. Thus, it is advisable to maintain the BP level that the patient presents before the initiation of EVT.

\section{Procedural BP}

Most studies investigating procedural BP levels reported a higher likelihood of poor outcomes after a prolonged duration of lower or higher BP. However, these two points require further discussion. First, these were post hoc analyses of studies that compared the route of anesthesia. Thus, the deleterious effect of low BP cannot be separated from that of anesthetics. ${ }^{48-50}$ Second, collateral perfusion through the LMC mainly works before recanalization. The collateral perfusion will instantaneously reverse back to physiological status as soon as the orthotropic flow is restored. ${ }^{5}$ Therefore, the procedural BP management strategy may need to distinguish whether recanalization is achieved.

Before recanalization, as in the pre-EVT period, the objective of BP management should be to ensure the viability of the ischemic penumbra. Prolonged exposure to low or high BP should be avoided. A mean arterial BP range between 70 and $90 \mathrm{~mm} \mathrm{Hg}$ was suggested by one study. ${ }^{49}$ After recanalization, the BP management strategy would follow that for the post-recanalization period.

\section{Post-recanalization period}

The primary goal of BP management after successful recanalization is to mitigate the risk of hemorrhagic complications and stabilize ischemic tissues. Randomized clinical trials to test the efficacy of EVT for anterior circulation LVO have specified some BP management instructions. The Evaluation Study of Congestive Heart Failure and Pulmonary Artery Catheterization Effectiveness (ESCAPE) trial recommended SBP values $\geq 150 \mathrm{~mm} \mathrm{Hg}$ 
while the artery remains occluded; controlling BP once reperfusion has been achieved while aiming for a normal BP in an individual is sensible. ${ }^{100} \mathrm{~A}$ recent EVT trial proposed SBP $<140$ $\mathrm{mm} \mathrm{Hg}$ after successful EVT. ${ }^{101}$ In general, higher BP levels during the acute period tend to stabilize after recanalization treatment. ${ }^{98}$ Post hoc analyses of the BEST study and the Safe Implementation of Thrombolysis in Stroke International Stroke Thrombolysis Registry (SITS-ISTR) identified that higher BP after EVT is associated with poor outcomes. ${ }^{72,74}$ Further studies and discussion should be conducted to investigate whether the unfavorable effect of higher-than-usual BP is reproduced consistently over the recanalization grades, that is, cases with post-EVT recanalization grades modified treatment in cerebral ischemia (mTICl) 2b, 2c, and 3. A patient who had $\mathrm{mTICl}$ of $2 b$ recanalization but with occlusion of a distal branch supplying the precentral gyrus may benefit from higher BP levels to support local LMC perfusion. Additionally, the association between $\mathrm{BP}$ variability and poor treatment outcomes has been consistently reported in the post-EVT period. Lastly, there is limited evidence that higher BP levels after recanalization cause hemorrhagic transformation.

Thus, the following rule of thumb may be considered until more evidence emerges.

(1) In the post-recanalization period, it is best to maintain the BP level of the patient.

(2) The practice of lowering SBP to less than $140 \mathrm{~mm} \mathrm{Hg}$ after successful recanalization is not based on proven evidence.

(3) We suggest monitoring BP levels after recanalization and treating only if BP levels are very high; for example, >185 $\mathrm{mm} \mathrm{Hg}$ systolic when IVT has already been offered or when recanalization grade $\mathrm{mTICl} 2 \mathrm{c}$ or 3 has been achieved.

(4) Higher BP levels after recanalization may portend unfavorable treatment outcomes.

\section{Research perspective}

Despite a large body of literature, current clinical guidelines provide limited recommendations regarding BP management strategies in the peri-EVT period. One obvious reason is the retrospective and observational design of published studies. However, BP can be easily measured and readily controlled by parenteral medications. Owing to constant fluctuation in BP during this period, clinical inertia, that is, ignoring outlier BP values, may creep unintentionally. The discrepancy between a prespecified BP target and achieved BP levels is not infrequent in real-world clinical practice. In a recent clinical trial, the BPBlood Pressure target in Acute Stroke to Reduce Hemorrhage after Endovascular Therapy (TARGET) study randomized 324 cases into an intensive SBP target (100 to $129 \mathrm{~mm} \mathrm{Hg}$ ) and a standard SBP target (130 to $185 \mathrm{~mm} \mathrm{Hg}$ ) during the 24 hours after EVT. The two groups were comparable in radiographic intraparenchymal hemorrhage at 24 to 36 hours, as well as functional recovery and safety outcomes. However, there was an unintended crossover between the assigned target group; patients in the intensive arm spent approximately a third of the duration in the SBP target range of the control arm. ${ }^{75}$ Such crossover was also noted in a prospective cohort from eight comprehensive stroke centers that grouped EVT patients into intensive $(<140 \mathrm{~mm} \mathrm{Hg})$, moderate $(<160 \mathrm{~mm} \mathrm{Hg})$, and usual $\left(<180 \mathrm{~mm} \mathrm{Hg}\right.$ ) SBP management groups. ${ }^{76}$ Despite significant benefits from the moderate target compared to the guideline-recommended target group, the mean SBP levels were almost identical in both groups. Studies focusing on prespecified SBP targeting after EVT need to consider the stabilizing trends of BP after treatment and the inadvertent effect of treating physicians' behavior and preconceptions.

\section{Summary measures for BP}

Repeated measures of BP over time were obtained from a single patient. However, in clinical practice, these measurements are recorded over various time intervals, thus providing only a screenshot of the dynamic readings in time. Considering that every cardiac beat generates SBP and diastolic BP (Figure 2A), the recorded $B P$ values represent only a fraction of the potentially available BP data. Therefore, to capture maximum information, researchers need to carefully choose indices such as BP level, BP variability, and BP trajectory (Figure 2).

BP level, usually presented as mean BP over a specific duration, expresses the status of $\mathrm{BP}$ at a particular time point or period. This level is intuitive to physicians, and the change in the BP level may provide practical information (Figure 2B). ${ }^{74}$ However, this measure does not capture information about the BP variation generated by every cardiac beat. Variability is a summary measure of the fluctuation of the measurements over a specific duration (Figure 2C). It is not easy to set up a specific threshold of BP variability that warrants clinical intervention, as accurately measuring variability requires a sufficient count of BP measurements to be calculated. It should also be acknowledged that variability indices are affected by the temporal density of BP measurements and BP levels. The absolute BP variability value may decrease during a high measurement density period, that is, during the EVT procedure. Short-term variability is also affected by physical activity, emotional stress, and circadian rhythm, all of which augment the complexity of interpretation of such data. ${ }^{102} \mathrm{BP}$ trajectories focus on identifying a specific group following a similar trend and pattern of 


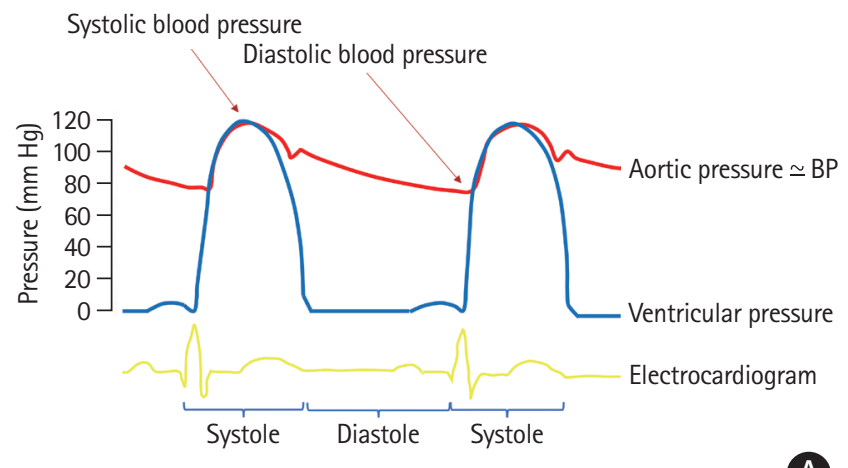

A

Variability of BP: quantification of the fluctuation over a specific time duration

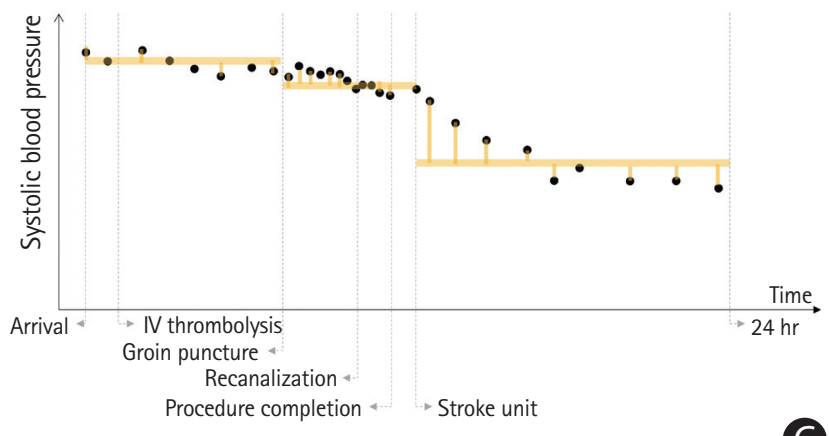

C
Levels of BP

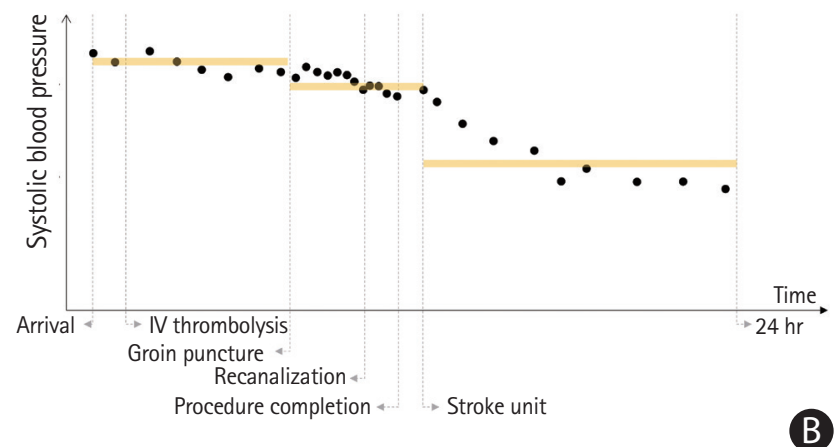

Trajectory of BP

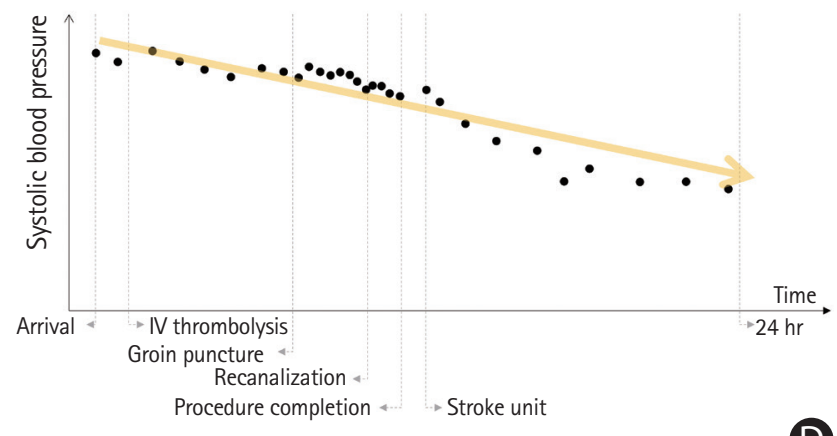

Figure 2. Characteristics of blood pressure measurements and summary indices. Systolic and diastolic blood pressure (BP) is determined during every cardiac cycle. Intermittent measurements in routine clinical practice may capture only a fraction of the available BP measurements. BP measurements can be obtained repeatedly and exhibit constant fluctuations (A). The measurement density of BPs may be different throughout acute in-hospital care, that is, pre-endovascular treatment (EVT), during the procedure, as well as post-EVT. BP measurements can be summarized using means, as highlighted by the yellow line in the figure. The average BP level is intuitive and easy to calculate, but it does not reflect the variability and fluctuations in BP measurements that occur in a patient (B). Fluctuations of BP can be described by various variability measures, including standard deviations, coefficient of variations, maximum decrements, and average real variability, to name a few. In general, variability measures are calculated by taking the differences between each measurement or the differences between specific values (yellow lines). However, such variability measures do not provide information on the time intervals of the measurements. Thus, the absolute BP variability values may decrease during high measurement density periods such as during EVT procedures (C). The trajectory group describes the overall path (yellow line) of BP measurements over a certain period of time. By using a mixture model, clusters of patients with similar patterns of BP measurements over a period of time may be identified and grouped. ${ }^{104}$ Five groups of acute BP trajectories were identified from a clinical registry of 8,000 stroke cases. ${ }^{103}$ Trajectory groups are easy to recognize in clinical practice even before the measurement period is completed. However, the trajectory group estimation process depends on the characteristics of the source data and the modeling specification, and thus, the generalizability of the model is limited (D). IV, intravenous.

the BP measurements over a certain period (Figure 2D). ${ }^{103,104}$ Trajectory grouping and estimation procedures currently require specific model specifications and are not widely applied to the acute stroke period.

\section{The relationship between leptomeningeal collaterals and blood pressure in patients with large vessel occlusions}

As discussed in this review, regional tissue perfusion after LVO is maintained by the LMC channels. The recruitment of these LMC channels is determined by the pressure gradient between the arterial blood flow generated by cardiac contraction and venous blood flow. Based on this simple and linear model, it is intuitive to suppose that cerebral tissue perfusion after LVO may be regulated through systemic BP management.

However, the small arteries and arterioles of the brain have CA capacity, which modulates the vascular diameter to maintain almost constant $\mathrm{CBF}$ in response to local perfusion pressure changes. Therefore, the brain tissue that may receive increased local CBF from augmenting systemic BP is likely to be either the ischemic core or the ischemic penumbra without autoregulatory function. A long history of hypertension may indicate impaired autoregulatory function..$^{105}$ Additionally, as the blood flow inversely corresponds to the fourth-order of the vascular luminal diameter, the LMC perfusion will not suffice to replace the normal physiologic CBF through anatomically intact large vessels.

Based on the above, the following can be stated: 
(1) The effect of systemic BP on blood flow distal to an LVO may vary based on the anatomic extent of the LMC channels and the remaining autoregulatory function.

(2) Ischemic brain injury may affect the vascular endothelium, pericytes, glia, and neuronal cells, and it prevents the maintenance of normal autoregulatory function. The autoregulatory function may also be affected by prior conditions, such as hypertension and diabetes mellitus.

(3) In general, LMC perfusion only provides inadequate blood flow that cannot sustain brain tissue viability for long.

(4) The BP management strategy for acute ischemic stroke patients may need to be personalized based on the individual assessment of the LMC channels and autoregulatory capacity.

Whether baseline hemodynamic status modifies the association between BP profiles and ischemic or functional outcomes is a fascinating research topic. ${ }^{106}$ This issue has recently gained interest with studies showing that poor baseline collaterals can aggravate the deleterious effects of higher BP levels or higher BP variability on clinical outcomes. ${ }^{51,77}$ The association between $\mathrm{BP}$ and stroke outcomes may also differ by baseline perfusion status, that is, the extent and grade of LMC and tissue perfusion. As discussed in the previous section, early infarct growth may be a function of time from onset, ischemic severity (i.e., baseline LMC perfusion), and tissue vulnerability. ${ }^{31,32}$ It can be speculated that in patients with poor LMCs after LVO, ischemic injury rapidly develops, and the only effective treatment strategy is to expedite recanalization. In contrast, in the presence of moderate LMCs, tissue viability mainly depends on systemic perfusion, and clinicians should be sensitive to even minute changes in BP. Meanwhile, in patients with excellent or good collaterals, one can expect a higher tolerance to modest BP fluctuations. This conjecture needs to be validated in future studies.

\section{Conclusions}

In current practice, stroke physicians use BP measurements as a proxy for brain perfusion pressure. Conceptually, the objective of BP management in the pre-recanalization phase is to maintain sufficient LMC perfusion. In the post-recanalization phase, the objective is to prevent hemorrhagic complications and stabilize the ischemic brain tissues. At present, the available research on $\mathrm{BP}$ management in $\mathrm{EVT}$ shows that higher $\mathrm{BP}$ on admission, lower BP levels post-recanalization, higher BP variability or variable trajectories, and prolonged durations of low BP during EVT are all associated with poor functional outcomes. However, the optimal BP level, variability, and trajectory for each phase are yet to be determined. Based on current anatomical and physiological knowledge, the ultimate goal is to directly gauge the amount and capacity of LMC perfusion after LVO to provide maximally available CBF to the ischemic brain until successful recanalization is achieved and to mitigate undesirable complications subsequent to ischemia and reperfusion. Given the heterogeneity of the anatomy and variability of the physiology of the LMC, understanding its behavior during stroke is now more pressing than ever. It is paramount that more novel mechanisms and parameters to assess regional brain perfusion and functioning CA capacity at the bedside are developed in order to individualize BP management in the periEVT period. ${ }^{52,78}$

\section{Disclosure}

The authors have no financial conflicts of interest.

\section{References}

1. Goyal M, Menon BK, van Zwam WH, Dippel DW, Mitchell PJ, Demchuk AM, et al. Endovascular thrombectomy after large-vessel ischaemic stroke: a meta-analysis of individual patient data from five randomised trials. Lancet 2016;387:17231731.

2. Yu I, Bang OY, Chung JW, Kim YC, Choi EH, Seo WK, et al. Admission diffusion-weighted imaging lesion volume in patients with large vessel occlusion stroke and Alberta Stroke Program Early CT Score of $\geq 6$ points: serial computed tomography-magnetic resonance imaging collateral measurements. Stroke 2019;50:3115-3120.

3. Albers GW. Late window paradox. Stroke 2018;49:768-771.

4. Winship IR. Cerebral collaterals and collateral therapeutics for acute ischemic stroke. Microcirculation 2015;22:228-236.

5. Brozici $M$, van der Zwan $A$, Hillen B. Anatomy and functionality of leptomeningeal anastomoses: a review. Stroke 2003;34: 2750-2762.

6. Cipolla MJ, McCall AL, Lessov N, Porter JM. Reperfusion decreases myogenic reactivity and alters middle cerebral artery function after focal cerebral ischemia in rats. Stroke 1997;28:176-180.

7. Gibo $H_{1}$ Carver CC, Rhoton AL Jr, Lenkey C, Mitchell RJ. Microsurgical anatomy of the middle cerebral artery. J Neurosurg 1981;54:151-169.

8. Gomes FB, Dujovny M, Umansky F, Berman SK, Diaz FG, Ausman Jl, et al. Microanatomy of the anterior cerebral artery. Surg Neurol 1986;26:129-141.

9. Zarrinkoob L, Ambarki $K$, Wåhlin $A$, Birgander R, Eklund A, Malm J. Blood flow distribution in cerebral arteries. J Cereb 
Blood Flow Metab 2015;35:648-654.

10. Jones EG. On the mode of entry of blood vessels into the cerebral cortex. J Anat 1970;106(Pt 3):507-520.

11. Duvernoy HM, Delon S, Vannson JL. Cortical blood vessels of the human brain. Brain Res Bull 1981;7:519-579.

12. Kennedy McConnell F, Payne S. The dual role of cerebral autoregulation and collateral flow in the circle of willis after major vessel occlusion. IEEE Trans Biomed Eng 2017;64: 1793-1802.

13. Aaslid R, Lindegaard KF, Sorteberg W, Nornes H. Cerebral autoregulation dynamics in humans. Stroke 1989;20:45-52.

14. Ainslie PN, Duffin J. Integration of cerebrovascular CO2 reactivity and chemoreflex control of breathing: mechanisms of regulation, measurement, and interpretation. Am J Physiol Regul Integr Comp Physiol 2009;296:R1473-R1495.

15. Peterson EC, Wang Z, Britz G. Regulation of cerebral blood flow. Int J Vasc Med 2011;2011:823525.

16. Asgari $S$, Bergsneider M, Hamilton R, Vespa P, Hu X. Consistent changes in intracranial pressure waveform morphology induced by acute hypercapnic cerebral vasodilatation. Neurocrit Care 2011;15:55-62.

17. Witthoft $A, E m$ Karniadakis $G$. A bidirectional model for communication in the neurovascular unit. J Theor Bio/ 2012;311:80-93.

18. Attwell D, Mishra A, Hall CN, O'Farrell FM, Dalkara T. What is a pericyte? J Cereb Blood Flow Metab 2016;36:451-455.

19. Ma J, Ma Y, Shuaib A, Winship IR. Impaired collateral flow in pial arterioles of aged rats during ischemic stroke. Trans/ Stroke Res 2020;11:243-253.

20. Chan SL, Sweet JG, Bishop N, Cipolla MJ. Pial collateral reactivity during hypertension and aging: understanding the function of collaterals for stroke therapy. Stroke 2016;47:16181625.

21. Biose IJ, Dewar D, Macrae IM, McCabe C. Impact of stroke co-morbidities on cortical collateral flow following ischaemic stroke. J Cereb Blood Flow Metab 2020;40:978-990.

22. Castro $P$, Azevedo $E$, Sorond F. Cerebral autoregulation in stroke. Curr Atheroscler Rep 2018;20:37.

23. Hecht N, Schrammel M, Neumann K, Müller MM, Dreier JP, Vajkoczy $P$, et al. Perfusion-dependent cerebral autoregulation impairment in hemispheric stroke. Ann Neurol 2021;89:358368.

24. Coyle P. Diameter and length changes in cerebral collaterals after middle cerebral artery occlusion in the young rat. Anat Rec 1984;210:357-364.

25. Morita Y, Fukuuchi Y, Koto A, Suzuki N, Isozumi K, Gotoh J, et al. Rapid changes in pial arterial diameter and cerebral blood flow caused by ipsilateral carotid artery occlusion in rats. Keio J Med 1997;46:120-127.
26. Rocha M, Jovin TG. Fast versus slow progressors of infarct growth in large vessel occlusion stroke: clinical and research implications. Stroke 2017;48:2621-2627.

27. Dirnagl U, Pulsinelli W. Autoregulation of cerebral blood flow in experimental focal brain ischemia. J Cereb Blood Flow Metab 1990;10:327-336.

28. Sandset EC, Anderson CS, Bath PM, Christensen H, Fischer U, Gąsecki D, et al. European Stroke Organisation (ESO) guidelines on blood pressure management in acute ischaemic stroke and intracerebral haemorrhage. Eur Stroke J 2021;6:48-89.

29. Powers WJ, Rabinstein AA, Ackerson T, Adeoye OM, Bam-

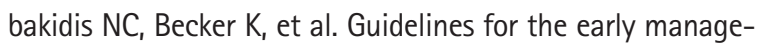
ment of patients with acute ischemic stroke: 2019 update to the 2018 guidelines for the early management of acute ischemic stroke: a guideline for healthcare professionals from the American Heart Association/American Stroke Association. Stroke 2019;50:e344-e418.

30. Jeong $H G$, Kim BJ, Kim $H$, Jung $C$, Han MK, Liebeskind DS, et al. Blood pressure drop and penumbral tissue loss in nonrecanalized emergent large vessel occlusion. Stroke 2019;50:26772684.

31. Puhr-Westerheide D, Tiedt S, Rotkopf LT, Herzberg M, Reidler $P$, Fabritius MP, et al. Clinical and imaging parameters associated with hyperacute infarction growth in large vessel occlusion stroke. Stroke 2019;50:2799-2804.

32. Broocks G, Rajput F, Hanning U, Faizy TD, Leischner H, Schön $\mathrm{G}$, et al. Highest lesion growth rates in patients with hyperacute stroke. Stroke 2019;50:189-192.

33. El Amki M, Glück C, Binder N, Middleham W, Wyss MT, Weiss T, et al. Neutrophils obstructing brain capillaries are a major cause of no-reflow in ischemic stroke. Cell Rep 2020;33:108260.

34. Liebeskind DS, Bracard $S$, Guillemin F, Jahan R, Jovin TG, Majoie $C B$, et al. eTICl reperfusion: defining success in endovascular stroke therapy. J Neurointerv Surg 2019;11:433-438.

35. Mistry EA, Mayer SA, Khatri P. Blood pressure management after mechanical thrombectomy for acute ischemic stroke: a survey of the StrokeNet sites. J Stroke Cerebrovasc Dis 2018;27:24742478.

36. Nogueira RG, Liebeskind DS, Sung G, Duckwiler G, Smith WS; $\mathrm{MERCl}$, et al. Predictors of good clinical outcomes, mortality, and successful revascularization in patients with acute ischemic stroke undergoing thrombectomy: pooled analysis of the Mechanical Embolus Removal in Cerebral Ischemia (MERCI) and Multi MERCI Trials. Stroke 2009;40:3777-3783.

37. Mulder MJ, Ergezen $S$, Lingsma HF, Berkhemer OA, Fransen PS, Beumer $D$, et al. Baseline blood pressure effect on the benefit and safety of intra-arterial treatment in MR CLEAN (Multicenter Randomized Clinical Trial of Endovascular 
Treatment of Acute Ischemic Stroke in the Netherlands). Stroke 2017;48:1869-1876.

38. Maïer B, Gory B, Taylor G, Labreuche J, Blanc R, Obadia M, et al. Mortality and disability according to baseline blood pressure in acute ischemic stroke patients treated by thrombectomy: a collaborative pooled analysis. J Am Heart Assoc 2017;6:e006484.

39. Van den Berg SA, Uniken Venema SM, Mulder MJ, Treurniet $\mathrm{KM}$, Samuels N, Lingsma HF, et al. Admission blood pressure in relation to clinical outcomes and successful reperfusion after endovascular stroke treatment. Stroke 2020;51:3205-3214.

40. Schönenberger $S$, Uhlmann L, Ungerer M, Pfaff J, Nagel S,

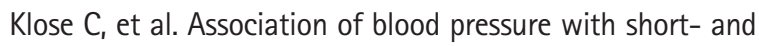
long-term functional outcome after stroke thrombectomy: post hoc analysis of the SIESTA trial. Stroke 2018;49:14511456.

41. Goyal N, Tsivgoulis G, Iftikhar S, Khorchid Y, Fawad Ishfaq M, Doss VT, et al. Admission systolic blood pressure and outcomes in large vessel occlusion strokes treated with endovascular treatment. J Neurointerv Surg 2017;9:451-454.

42. Anadani $M$, Lapergue $B$, Blanc $R$, Kyheng $M$, Labreuche J, Machaa MB, et al. Admission blood pressure and outcome of endovascular therapy: secondary analysis of ASTER trial. $J$ Stroke Cerebrovasc Dis 2020;29:105347.

43. Davis MJ, Menon BK, Baghirzada LB, Campos-Herrera CR, Goyal M, Hill MD, et al. Anesthetic management and outcome in patients during endovascular therapy for acute stroke. Anesthesiology 2012;116:396-405.

44. Jagani M, Brinjikji W, Rabinstein AA, Pasternak JJ, Kallmes DF. Hemodynamics during anesthesia for intra-arterial therapy of acute ischemic stroke. J Neurointerv Surg 2016;8:883-888.

45. Rasmussen M, Espelund US, Juul N, Yoo AJ, Sørensen LH,

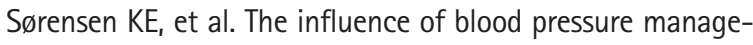
ment on neurological outcome in endovascular therapy for acute ischaemic stroke. Br J Anaesth 2018;120:1287-1294.

46. Pikija S, Trkulja V, Ramesmayer C, Mutzenbach JS, Killer-Ober-

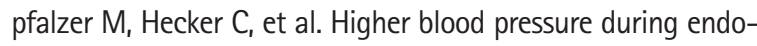
vascular thrombectomy in anterior circulation stroke is associated with better outcomes. J Stroke 2018;20:373-384.

47. Petersen NH, Ortega-Gutierrez S, Wang A, Lopez GV, Strander $S$, Kodali $S$, et al. Decreases in blood pressure during thrombectomy are associated with larger infarct volumes and worse functional outcome. Stroke 2019;50:1797-1804.

48. Valent A, Sajadhoussen A, Maier B, Lapergue B, Labeyrie MA, Reiner $P$, et al. A $10 \%$ blood pressure drop from baseline during mechanical thrombectomy for stroke is strongly associated with worse neurological outcomes. J Neurointerv Surg 2020;12:363-369.
49. Rasmussen $M$, Schönenberger $S$, Hendèn PL, Valentin JB, Espelund US, Sørensen LH, et al. Blood pressure thresholds and neurologic outcomes after endovascular therapy for acute ischemic stroke: an analysis of individual patient data from 3 randomized clinical trials. JAMA Neuro/ 2020;77:622-631.

50. Samuels $N$, van de Graaf RA, van den Berg CAL, Nieboer $D$, Eralp I, Treurniet KM, et al. Blood pressure during endovascular treatment under conscious sedation or local anesthesia. Neurology 2021;96:e171-e181.

51. Maïer B, Dargazanli C, Bourcier R, Kyheng M, Labreuche J, Mosimann PJ, et al. Effect of steady and dynamic blood pressure parameters during thrombectomy according to the collateral status. Stroke 2020;51:1199-1206.

52. Petersen NH, Silverman A, Strander SM, Kodali S, Wang A, Sansing $\mathrm{LH}$, et al. Fixed compared with autoregulation-oriented blood pressure thresholds after mechanical thrombectomy for ischemic stroke. Stroke 2020;51:914-921.

53. Löwhagen Hendén $P$, Rentzos $A$, Karlsson JE, Rosengren $L$, Sundeman $H$, Reinsfelt $B$, et al. Hypotension during endovascular treatment of ischemic stroke is a risk factor for poor neurological outcome. Stroke 2015;46:2678-2680.

54. John S, Hazaa W, Uchino K, Toth G, Bain M, Thebo U, et al. Lower intraprocedural systolic blood pressure predicts good outcome in patients undergoing endovascular therapy for acute ischemic stroke. Interv Neurol 2016;4:151-157.

55. Whalin MK, Halenda KM, Haussen DC, Rebello LC, Frankel MR, Gershon RY, et al. Even small decreases in blood pressure during conscious sedation affect clinical outcome after stroke thrombectomy: an analysis of hemodynamic thresholds. AJNR Am J Neuroradiol 2017;38:294-298.

56. Athiraman U, Sultan-Qurraie A, Nair B, Tirschwell DL, Ghodke $B$, Havenon AD, et al. Endovascular treatment of acute ischemic stroke under general anesthesia: predictors of good outcome. J Neurosurg Anesthesiol 2018;30:223-230.

57. Treurniet KM, Berkhemer OA, Immink RV, Lingsma HF, Wardvan der Stam VM, Hollmann MW, et al. A decrease in blood pressure is associated with unfavorable outcome in patients undergoing thrombectomy under general anesthesia. J Neurointerv Surg 2018;10:107-111.

58. Pikija S, Millesi K, Killer-Oberpfalzer M, Mutzenbach JS, Sztriha LK, Füssel MU, et al. Blood pressure characteristics in patients with acute basilar artery occlusion undergoing endovascular thrombectomy. Sci Rep 2019;9:13224.

59. Fandler-Höfler $S$, Heschl S, Argüelles-Delgado P, Kneihsl M, Hassler E, Magyar M, et al. Single mean arterial blood pressure drops during stroke thrombectomy under general anaesthesia are associated with poor outcome. J Neurol 2020;267:13311339. 
60. Xu C, Lin G, Zhang Z, Jin T, Li N, Mao H, et al. Prolonged duration of blood pressure drops during general anesthesia is associated with worse outcomes after mechanical thrombectomy. Front Neurol 2021;12:640841.

61. Chen $M$, Kronsteiner D, Pfaff J, Schieber S, Jäger L, Bendszus $M$, et al. Hemodynamic status during endovascular stroke treatment: association of blood pressure with functional outcome. Neurocrit Care 2021 Jun 17 [Epub]. https://doi.org/10.1007/ s12028-021-01229-w.

62. Südfeld S, Brechnitz $S$, Wagner JY, Reese PC, Pinnschmidt HO, Reuter DA, et al. Post-induction hypotension and early intraoperative hypotension associated with general anaesthesia. Br J Anaesth 2017;119:57-64.

63. Schönenberger S, Uhlmann L, Hacke W, Schieber S, Mundiyanapurath S, Purrucker JC, et al. Effect of conscious sedation vs general anesthesia on early neurological improvement among patients with ischemic stroke undergoing endovascular thrombectomy: a randomized clinical trial. JAMA 2016;316:1986-1996.

64. Simonsen CZ, Yoo AJ, Sørensen LH, Juul N, Johnsen SP, Andersen $G$, et al. Effect of general anesthesia and conscious sedation during endovascular therapy on infarct growth and clinical outcomes in acute ischemic stroke: a randomized clinical trial. JAMA Neurol 2018;75:470-477.

65. Goyal N, Tsivgoulis G, Pandhi A, Chang JJ, Dillard K, Ishfaq MF, et al. Blood pressure levels post mechanical thrombectomy and outcomes in large vessel occlusion strokes. Neurology 2017;89:540-547.

66. Cernik D, Sanak D, Divisova P, Kocher M, Cihlar F, Zapletalova $J$, et al. Impact of blood pressure levels within first 24 hours after mechanical thrombectomy on clinical outcome in acute ischemic stroke patients. J Neurointerv Surg 2019;11:735-739.

67. Maier IL, Tsogkas I, Behme D, Bähr M, Knauth M, Psychogios MN, et al. High systolic blood pressure after successful endovascular treatment affects early functional outcome in acute ischemic stroke. Cerebrovasc Dis 2018;45:18-25.

68. Cheng $H, X u C_{1}$ Jin $X$, Chen Y, Zheng X, Shi F, et al. Association of blood pressure at successful recanalization and parenchymal hemorrhage after mechanical thrombectomy with general anesthesia. Front Neurol 2020;11:582639.

69. Matusevicius M, Cooray C, Bottai M, Mazya M, Tsivgoulis G, Nunes AP, et al. Blood pressure after endovascular thrombectomy: modeling for outcomes based on recanalization status. Stroke 2020;51:519-525.

70. Mistry EA, Sucharew H, Mistry AM, Mehta T, Arora N, Starosciak AK, et al. Blood Pressure after Endovascular Therapy for Ischemic Stroke (BEST): a multicenter prospective cohort study. Stroke 2019;50:3449-3455.
71. Bennett AE, Wilder MJ, McNally JS, Wold JJ, Stoddard GJ, Majersik JJ, et al. Increased blood pressure variability after endovascular thrombectomy for acute stroke is associated with worse clinical outcome. J Neurointerv Surg 2018;10:823-827.

72. Mistry EA, Mehta T, Mistry A, Arora N, Starosciak AK, De Los Rios La Rosa F, et al. Blood pressure variability and neurologic outcome after endovascular thrombectomy: a secondary analysis of the BEST Study. Stroke 2020;51:511-518.

73. Kim TJ, Park HK, Kim JM, Lee JS, Park SH, Jeong HB, et al. Blood pressure variability and hemorrhagic transformation in patients with successful recanalization after endovascular recanalization therapy: a retrospective observational study. Ann Neurol 2019;85:574-581.

74. Anadani M, Matusevicius $M$, Tsivgoulis $G$, Peeters $A$, Nunes $A P$, Mancuso $M$, et al. Magnitude of blood pressure change and clinical outcomes after thrombectomy in stroke caused by large artery occlusion. Eur J Neurol 2021 ;28:1922-1930.

75. Mazighi M, Richard S, Lapergue B, Sibon I, Gory B, Berge J, et al. Safety and efficacy of intensive blood pressure lowering after successful endovascular therapy in acute ischaemic stroke (BP-TARGET): a multicentre, open-label, randomised controlled trial. Lancet Neurol 2021;20:265-274.

76. Anadani M, Arthur AS, Tsivgoulis G, Simpson KN, Alawieh A, Orabi $Y$, et al. Blood pressure goals and clinical outcomes after successful endovascular therapy: a multicenter study. Ann Neurol 2020;87:830-839.

77. Liu D, Nie $X$, Pan Y, Yan H, Pu Y, Wei Y, et al. Adverse outcomes associated with higher mean blood pressure and greater blood pressure variability immediately after successful embolectomy in those with acute ischemic stroke, and the influence of pretreatment collateral circulation status. $J$ Am Heart Assoc 2021; 10:e019350.

78. Castro P, Ferreira F, Nguyen CK, Payabvash S, Ozan Tan C, So-

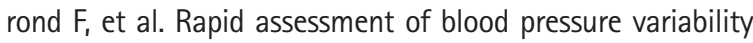
and outcome after successful thrombectomy. Stroke 2021;52: e531-e535.

79. Martins Al, Sargento-Freitas J, Silva F, Jesus-Ribeiro J, Correia I, Gomes JP, et al. Recanalization modulates association between blood pressure and functional outcome in acute ischemic stroke. Stroke 2016;47:1571-1576.

80. Mistry EA, Mistry AM, Nakawah MO, Khattar NK, Fortuny EM, Cruz AS, et al. Systolic blood pressure within 24 hours after thrombectomy for acute ischemic stroke correlates with outcome. J Am Heart Assoc 2017;6:e06167.

81. Chang JY, Jeon SB, Lee JH, Kwon OK, Han MK. The relationship between blood pressure variability, recanalization degree, and clinical outcome in large vessel occlusive stroke after an intra-arterial thrombectomy. Cerebrovasc Dis 2018;46:279-286. 
82. Martins Al, Sargento-Freitas J, Jesus-Ribeiro J, Correia I, Cardoso $\mathrm{L}$, Gomes JP, et al. Blood pressure variability in acute ischemic stroke: the role of early recanalization. Eur Neurol 2018;80:6367.

83. Chang JY, Jeon SB, Jung C, Gwak DS, Han MK. Postreperfusion blood pressure variability after endovascular thrombectomy affects outcomes in acute ischemic stroke patients with poor collateral circulation. Front Neurol 2019;10:346.

84. Cho BH, Kim JT, Lee JS, Park MS, Kang KW, Choi KH, et al. Associations of various blood pressure parameters with functional outcomes after endovascular thrombectomy in acute ischaemic stroke. Eur J Neurol 2019;26:1019-1027.

85. Choi KH, Kim JM, Kim JH, Kim JT, Park MS, Choi SM, et al. Optimal blood pressure after reperfusion therapy in patients with acute ischemic stroke. Sci Rep 2019;9:5681.

86. Zhang $T$, Wang $X_{1}$ Wen $C$, Zhou F, Gao S, Zhang $X$, et al. Effect of short-term blood pressure variability on functional outcome after intra-arterial treatment in acute stroke patients with large-vessel occlusion. BMC Neurol 2019;19:228.

87. Anadani $M$, Arthur AS, Alawieh A, Orabi $Y$, Alexandrov $A$, Goyal $N$, et al. Blood pressure reduction and outcome after endovascular therapy with successful reperfusion: a multicenter study. J Neurointerv Surg 2020;12:932-936.

88. Anadani M, de Havenon A, Yaghi S, Mehta T, Arora N, Starosciak $A K$, et al. Blood pressure reduction and outcome after endovascular therapy: a secondary analysis of the BEST study. J Neurointerv Surg 2021;13:698-702.

89. Chu HJ, Lin $\mathrm{CH}_{1}$ Chen $\mathrm{CH}$, Hwang YT, Lee $\mathrm{M}$, Lee $\mathrm{CW}$, et al. Effect of blood pressure parameters on functional independence in patients with acute ischemic stroke in the first 6 hours after endovascular thrombectomy. J Neurointerv Surg 2020;12:937-941.

90. Carvalho Dias M, Gabriel D, Saraiva M, Campos D, Requena M, García-Tornel Á, et al. Spontaneous systolic blood pressure drop early after mechanical thrombectomy predicts dramatic neurological recovery in ischaemic stroke patients. Eur Stroke J 2020;5:362-369.

91. Ding X, Xu C, Zhong W, Gong X, Zhou Y, Chen Z, et al. Association of maximal systolic blood pressure with poor outcome in patients with hyperattenuated lesions on immediate NCCT after mechanical thrombectomy. J Neurointerv Surg 2020;12:127-131.

92. McCarthy DJ, Ayodele M, Luther E, Sheinberg D, Bryant JP, Elwardany 0 , et al. Prolonged heightened blood pressure following mechanical thrombectomy for acute stroke is associated with worse outcomes. Neurocrit Care 2020;32:198-205.

93. Gigliotti MJ, Padmanaban V, Richardson A, Simon SD, Church EW, Cockroft KM. Effect of blood pressure management strategies on outcomes in patients with acute ischemic stroke after successful mechanical thrombectomy. World Neurosurg 2021;148:e635-e642.

94. Han $B$, Sun $X_{1}$ Liu $R_{1}$ Tong $X_{1}$ Jia B, Mo D, et al. Impact of the perioperative blood pressure on clinical outcome after thrombectomy in acute basilar artery occlusion. J Stroke Cerebrovasc Dis 2021;30:105590.

95. Huang $X$, Guo H, Yuan L, Cai Q, Zhang M, Zhang Y, et al. Blood pressure variability and outcomes after mechanical thrombectomy based on the recanalization and collateral status. Ther Adv Neurol Disord 2021;14:1756286421997383.

96. Malhotra K, Goyal N, Katsanos AH, Filippatou A, Mistry EA, Khatri $P$, et al. Association of blood pressure with outcomes in acute stroke thrombectomy. Hypertension 2020;75:730739.

97. De Havenon A, Bennett A, Stoddard GJ, Smith G, Chung L, O'Donnell $S$, et al. Determinants of the impact of blood pressure variability on neurological outcome after acute ischaemic stroke. Stroke Vasc Neurol 2017;2:1-6.

98. Mattle HP, Kappeler L, Arnold M, Fischer U, Nedeltchev K, Remonda $L$, et al. Blood pressure and vessel recanalization in the first hours after ischemic stroke. Stroke 2005;36:264-268.

99. Brott $T$, Lu M, Kothari R, Fagan SC, Frankel M, Grotta JC, et al. Hypertension and its treatment in the NINDS rt-PA stroke trial. Stroke 1998;29:1504-1509.

100. Goyal M, Demchuk AM, Menon BK, Eesa M, Rempel JL, Thornton J, et al. Randomized assessment of rapid endovascular treatment of ischemic stroke. N Engl J Med 2015;372:1019-1030.

101. Jovin TG, Saver JL, Ribo M, Pereira V, Furlan A, Bonafe $A$, et al. Diffusion-weighted imaging or computerized tomography perfusion assessment with clinical mismatch in the triage of wake up and late presenting strokes undergoing neurointervention with Trevo (DAWN) trial methods. Int J Stroke 2017;12:641-652.

102. Parati G, Ochoa JE, Lombardi C, Bilo G. Assessment and management of blood-pressure variability. Nat Rev Cardiol 2013; 10:143-155.

103. Kim BJ, Cho YJ, Hong KS, Lee J, Kim JT, Choi KH, et al. Trajectory groups of 24-hour systolic blood pressure after acute ischemic stroke and recurrent vascular events. Stroke 2018;49:1836-1842.

104. Nagin DS, Odgers CL. Group-based trajectory modeling in clinical research. Annu Rev Clin Psychol 2010;6:109-138.

105. Müller M, Österreich M, Lakatos L, Hessling AV. Cerebral macro- and microcirculatory blood flow dynamics in successfully treated chronic hypertensive patients with and without white mater lesions. Sci Rep 2020;10:9213.

106. Anadani M, de Havenon A, Mistry $E$, Anderson CS. Blood pressure management after endovascular therapy: an ongoing debate. Stroke 2021;52:e263-e265. 